\title{
PENGARUH PEMBIAYAAN IJARAH, NON-PERFORMING FINANCING DAN FINANCING TO DEPOSIT RATIO TERHADAP RETURN ON ASSETS PADA UNIT USAHA SYARIAH TAHUN 2018-2020
}

\author{
Rini Malinda Sari, Fena Ulfa Aulia ", Iis Nurul Anami, Atika Salsabila \\ Institut Agama Islam Negeri (IAIN) Madura, Pamekasan, Indonesia \\ rinisukarji31@gmail.com, fenaulfa@iainmadura.ac.id, \\ iisnurulanami012@gmail.com, atika30072000@gmail.com
}

Received: Feb 21, 2021 Revised: Mar 12, 2021 Accepted: Mar 23, 2021 Published: Apr 09, 2021

\begin{abstract}
This study aims to determine the effect of ijarah financing, non-performing financing $(N P F)$ and financing to deposit ratio (FDR) on return on assets (ROA) in Islamic business units (IBU) in 2018-2020. In this study, secondary data is used in the form of published quarterly financial reports of Islamic business units which are obtained from the website of the Financial Services Authority. The method used in this research is multiple linear regressions. The results of this study indicate that partially the ijarah financing variable has no significant effect on ROA, while NPF and FDR affect ROA. Ijarah financing cannot be used as a partial determining factor for ROA for IBU, but simultaneously ijarah financing, NPF and FDR can be used as a determining factor for ROA for IBU. Stakeholders can use the NPF and FDR variables as determinants of the level of ROA of an IBU.
\end{abstract}

Keywords: Ijarah Financing, Non-Performing Financing, Financing To Deposit Ratio, Return On Assets, Islamic Business Units.

\begin{abstract}
ABSTRAK
Penelitian ini bertujuan untuk mengetahui pengaruh pembiayaan ijarah, non performing financing (NPF) dan financing to deposit ratio (FDR) terhadap return on assets (ROA) pada unit usaha syariah (UUS) tahun 2018-2020. Dalam penelitian ini menggunakan data sekunder berupa laporan keuangan triwulan unit usaha syariah yang dipublikasikan yang didapatkan dari website otoritas jasa keuangan. Metode yang digunakan dalam penelitian ini adalah regresi linear berganda. Hasil penelitian ini menunjukkan bahwa secara parsial variabel pembiayaan ijarah tidak berpengaruh secara signifikan terhadap ROA, sedangkan NPF dan FDR mempengaruhi ROA. Pembiayaan ijarah tidak dapat digunakan sebagai faktor penentu ROA bagi UUS secara parsial, namun secara simultan pembiayaan ijarah, NPF dan FDR dapat dijadikan sebagai faktor penentu ROA bagi UUS. Stakeholder dapat menggunakan variabel NPF dan FDR sebagai penentu tinggi rendahnya ROA suatu UUS.
\end{abstract}

Kata Kunci: Pembiayaan Ijarah, Non-Performing Financing, Financing To Deposit Ratio, Return On Assets, Unit Usaha Syariah. 


\section{PENDAHULUAN}

Bank syariah pada awalnya dikembangkan sebagai suatu respon dari kelompok ekonomi dan praktisi perbankan Muslim yang berupaya mengakomodasi desakan dari berbagai pihak yang menginginkan agar tersedia jasa transaksi keuangan yang dilaksanakan sejalan dengan nilai moral dan prinsipprinsp syariah Islam (Marimin et al. 2015, 2). Menurut Kettel dalam (Ghozali et al. 2019) disebutkan bahwa berdasarkan wilayah ekonomi, bank syariah pertama di Asia Tenggara didirikan di Malaysia dengan nama bank Islam Malaysia berhard pada tahun 1983. Sebagai negara dengan mayoritas Muslim terbesar di dunia, peluang dan kebutuhan perbankan yang berbasis syariah juga merambah di negara Asia Tenggara lainnya yaitu Indonesia. Awal berdirinya bank syariah di Indonesia diawali dengan berdirinya bank Muamalat pada 01 November 1991. Meskipun dalam perkemabangannya tidak secepat perbankan syariah di Malaysia, Indonesia termasuk dalam negara ASEAN yang memiliki variasi beragam dalam pengembangan perbankan syariah (Ghozali et al. 2019).

Di Indonesia, bank syariah menurut jenisnya dibagi menjadi dua, yaitu bank umum syariah (BUS) dan bank pembiayaan rakyat syariah (BPRS). Kemudian dalam perbankan syariah juga terdapat unit usaha syariah (UUS) yang merupakan unit kerja dari kantor pusat bank umum konvensional yang berfungsi sebagai kantor induk dari kantor atau unit yang melaksanakan kegiatan usaha berdasarkan prinsip syariah, atau unit kerja di kantor cabang dari suatu bank yang berkedudukan di luar negeri, yang melaksanakan kegiatan usaha secara konvensional yang berfungsi sebagai kantor induk dari kantor cabang pembantu syariah dan/atau unit syariah. Berikut ini merupakan data dari jumlah kantor layanan syariah dari unit usaha syariah per Juni 2020.

Tabel 1. Jumlah Kantor Layanan Syariah dari Unit Usaha Syariah

\begin{tabular}{clccc}
\hline \multirow{2}{*}{ No. } & \multirow{2}{*}{ Nama Unit Usaha Syariah } & \multicolumn{3}{c}{ Tahun } \\
\cline { 3 - 5 } & & $\mathbf{2 0 1 8}$ & $\mathbf{2 0 1 9}$ & $\mathbf{2 0 2 0}$ \\
\hline 1 & PT. Bank Danamon Indonesia, Tbk & 401 & 434 & 419 \\
2 & PT. Bank Permata, Tbk & 299 & 289 & 288 \\
3 & PT. Maybank Indonesia, Tbk & 372 & 359 & 354 \\
4 & PT. CIMB Niaga, Tbk & 119 & 122 & 123 \\
5 & PT. OCBC NISP, Tbk & 256 & 230 & 204 \\
6 & PT. Bank Sinarmas & 39 & 153 & 158 \\
7 & PT. Bank Tabungan Negara & 298 & 340 & 339 \\
8 & (Persero), Tbk & & & \\
9 & PT. BPD DKI & 242 & 243 & 242 \\
10 & PT. BPD DIY BPD Jateng & 34 & 38 & 38 \\
11 & PT. BPD Jatim, Tbk & 156 & 156 & 156 \\
12 & PT. BPD Sumut & 191 & 191 & 195 \\
13 & PT. BPD Jambi & 121 & 121 & 121 \\
14 & PT. BPD Sumbar & 29 & 30 & 30 \\
15 & PT. BPD Riau dan Keppri & 31 & 31 & 119 \\
16 & PT. BPD Sumsel dan Babel & 52 & 52 & 52 \\
\hline
\end{tabular}




\begin{tabular}{llccc}
\hline 17 & PT. BPD Kalsel & 48 & 49 & 49 \\
18 & PT. BPD Kalbar & 65 & 65 & 65 \\
19 & PT. BPD Kaltim & 26 & 26 & 26 \\
20 & PT. BPD Nusa Tenggara Barat & - & - & - \\
\hline \multicolumn{2}{c}{ Jumlah } & $\mathbf{2 7 9 7}$ & $\mathbf{2 9 4 9}$ & $\mathbf{2 9 9 8}$ \\
\hline
\end{tabular}

Sumber: Otoritas Jasa Keuangan Indonesia

Pembiayaan dalam unit usaha syariah, khususnya di Indonesia sendiri, memiliki berbagai macam skema dan produk-produk pembiayaan. Salah satunya adalah pembiayaan dengan akad ijarah. Pembiayaan ijarah merupakan akad untuk menjual manfaat yang dilakukan oleh seseorang dengan orang lain menggunakan ketentuan syariat Islam. Pembiayaan ijarah ini mempunyai konsep yang berbeda dengan konsep kredit pada bank konvensional, pembiayaan ijarah juga dikatakan sebagai pendorong bagi sektor usaha karena pembiayaan ijarah mempunyai keistimewaan dibandingkan dengan jenis pembiayaan syariah lainnya. Keistimewaan tersebut adalah bahwa untuk memulai kegiatan usahanya, pengusaha tidak perlu memiliki barang modal terlebih dahulu, melainkan dapat melakukan penyewaan kepada lembaga keuangan syariah, sehingga pengusaha tidak dibebankan dengan kewajiban menyerahkan jaminan, maka dapat dikatakan bahwa pembiayaan ijarah lebih menarik dibandingkan jenis pembiayaan lainnya seperti mudharabah dan musyarakah (Santoso and Anik 2015, 2). Perkembangan pembiayaan pada UUS dapat dilihat pada grafik dibawah ini.

\section{Gambar 1. Komposisi Pembiayaan Yang Diberikan Unit Usaha Syariah Tahun 2018-2020 (Dalam Miliar)}

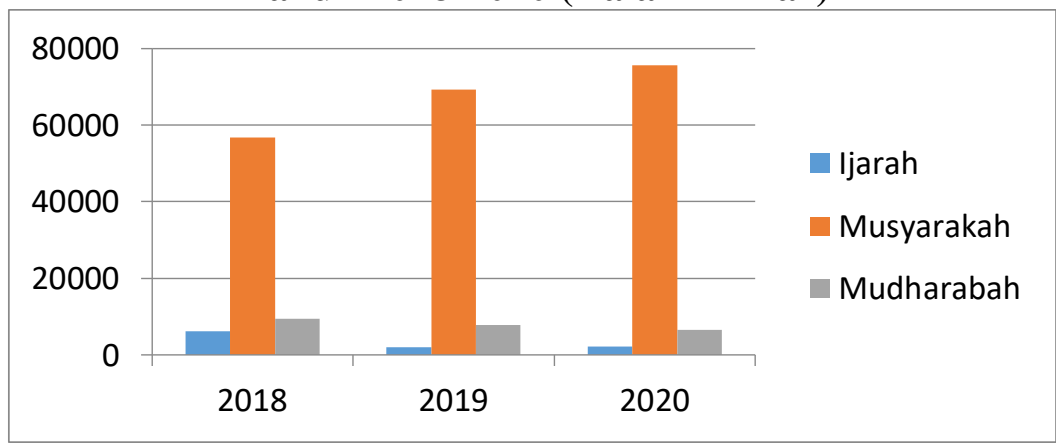

Sumber: Otoritas Jasa Keuangan Indonesia (data olahan)

Pada Gambar 1 pembiayaan ijarah dari tahun 2018-2020 cenderung turun, dimana tahun 2020 merupakan angka terendah. Hal ini juga terjadi pada pembiayaan mudharabah. Sedangkan pembiayaan musyarakah terlihat konsisten dan cenderung naik hingga tahun 2020. Pembiayaan ijarah merupakan pembiayaan yang memiliki kontribusi kecil dalam UUS. Hal ini disebabkan karena model pembiayaan ijarah mempunyai risiko relatif tinggi, dimana terdapat masalah ketidakpastian pendapatan keuntungan, sehingga menyebabkan UUS kurang berminat dalam menyalurkan pembiayaan dengan akad tersebut.

Praktik pembiayaan dengan menggunakan akad ijarah di Malaysia lebih dikenal sebagai akad ijarah thumma bai' dengan nama produk/jasa bank syariah hire purchase-I (Ascarya 2006). Secara konseptual, akad ini mirip dengan akad ijarah muntahiyah bit tamlik (IMBT) di Indonesia, yaitu penyewa menyewa 
barang dan sepakat membelinya dengan cara dicicil sehingga pada akhir masa sewa terjadi pemindahan hak kepemilikan (Imam 2021). Berbeda dengan akad ijarah thumma bai, akad ijarah di Indonesia hanya berupa akad menyewa objek sewa tanpa diikuti pemindahan hak kepemilikan di akhir masa sewa. Penyewa hanya membayar uang sewa atas objek yang disewa kepada pemilik objek sewa.

Banyak faktor yang mempengaruhi perbankan syariah dalam menyalurkan pembiayaan, baik faktor yang berasal dari internal maupun faktor yang berasal dari eksternal. Untuk melihat kondisi internal perbankan, biasanya pihak perbankan merujuk pada laporan keuangan yang diindikasi dengan berbagai rasio keuangan. Beberapa rasio keuangan yang sering digunakan untuk menilai kondisi internal dalam suatu perbankan syariah adalah rasio $N P F$ dan FDR.

Berdasarkan statistik perbankan syariah yang dikeluarkan otoritas jasa keuangan (OJK), pembiayaan yang disalurkan BUS dan UUS sepanjang semester I/2019 tumbuh 12,90 persen secara yoy. Pembiayaan sebesar Rp333,1 triliun dialirkan bank syariah, lebih tinggi dari jumlah pembiayaan setahun sebelumnya yakni Rp295 triliun. Pertumbuhan ini menjadi yang kedua tertinggi sepanjang paruh pertama tahun berjalan dalam kurun 5 tahun terakhir. Kenaikan pembiayaan tertinggi sepanjang paruh pertama 2015-2019 terjadi pada semester I/2017 yang mencapai 19,3 persen secara yoy. Saat itu, pembiayaan meningkat dari Rp222,2 triliun pada semester I/2016 menjadi Rp265,3 triliun setahun setelahnya.

Pertumbuhan pembiayaan bank syariah diikuti dengan menurunnya rasio pembiayaan bermasalah NPF BUS. Berdasarkan data yang sama, rasio NPF BUS hingga akhir Juni 2019 turun 47 basis poin (bps) menjadi 3,36 persen secara yoy. Penurunan rasio NPF BUS sepanjang paruh pertama 2019 melambat dibanding periode sebelumnya. Pada paruh pertama 2018 rasio NPF BUS turun 64 basis poin secara yoy, dan setahun sebelumnya penurunan mencapai $121 \mathrm{bps}$.

Pada UUS, rasio NPF justru mengalami kenaikan di periode yang sama. Rasio pembiayaan bermasalah di UUS naik 81 bps menjadi 3,09 persen. Kenaikan ini menjadi yang pertama sejak 2015. Sepanjang paruh pertama 2015-2018 rasio $N P F$ UUS selalu turun. Semester I/2018 rasio NPF UUS tercatat di anak 2,28 persen.

FDR BUS pada kuartal III 2019 berdasarkan data statistik perbankan syariah OJK adalah sebesar $80,85 \%$. FDR yang dianggap ideal bagi perbankan syariah adalah sebesar $95 \%-98 \%$. Namun, FDR perbankan syariah ini naik turun selama beberapa waktu. Tercatat FDR BUS pada tahun 2016 adalah sebesar 85,99\%, lumayan tinggi. Sedangkan FDR BUS di tahun 2017 dan 2018 berturutturut adalah sebesar 79,61\% dan 78,53\%. Sedangkan FDR Unit Usaha Syariah (UUS) berdasarkan data statistik perbankan syariah OJK pada tahun 2016, 2017, 2018, serta kuartal III 2019 berturut-turut adalah sebesar 96,70\%, 99,39\%, $103,22 \%$, serta $103,30 \%$.

Rasio yang digunakan sebagai indikator untuk mengukur kemampuan UUS dalam memperoleh laba secara keseluruhan adalah $R O A$. Apabila $R O A$ suatu bank besar, maka semakin besar pula keuntungan yang akan didapat bank tersebut. $R O A$ merupakan perbandigan antara laba sebelum pajak dengan rata-rata total asset yang menunjukan kemampuan keseluruhan aktiva yang digunakan untuk menghasilkan keuntungan. Beberapa rasio keuangan yang mempengaruhi ROA adalah capital adequacy ratio $(C A R), F D R, N P F$ dan Biaya Operasional terhadap pendapatan operasional (BOPO). UUS yeng menghasilkan return tinggi 
memiliki kecenderungan untuk memperluas usahanya. Maka dari itu pada penelitian ini menggunakan $R O A$ sebagai tolok ukur kinerja perbankan khususnya dalam meneliti tentang UUS.

Penelitian terdahulu yang dilakukan oleh (Rizqi et al. 2017) menemukan bahwa mudharabah berpengaruh positif signifikan terhadap profitabilitas, musyarakah berpengaruh negatif signifikan terhadap profitabilitas dan ijarah tidak berpengaruh signifikan terhadap profitabilitas. Hal ini berbeda dengan hasil penelitian (Permata et al. 2014) menemukan bahwa pembiayaan mudharabah berpengaruh negatif signifikan terhadap tingkat profitabilitas dan pembiayaan musyarakah berpengaruh signifikan dan positif terhadap tingkat profitabilitas.

Penelitian yang dilakukan oleh (Yusuf 2017) menunjukkan bahwa FDR memiliki pengaruh terhadap ROA BUS. Sedangkan penelitian yang dilakukan oleh (Roy 2018) menunjukkan bahwa NPF dan FDR tidak memiliki pengaruh yang signifikan terhadap ROA UUS di Indonesia. Penelitian ini memilih UUS karena laporan keuangan yang disediakan lebih lengkap, sesuai dengan data yang dibutuhkan dalam penelitian. Oleh sebab itu penelitian ini bertujuan untuk mengetahui pengaruh pembiayaan ijarah, NPF dan FDR terhadap ROA pada UUS tahun 2018-2020.

\section{TELAAH LITERATUR}

\section{Konsep Pembiayaan Ijarah}

Menurut bahasa, ijarah berarti sewa atau upah yang menjual belikan suatu manfaat dari harta atau benda (Mas'adi 2002, 181). Sedangkan menurut istilah suatu akad yang memiliki manfaat dan tujuan yang jelas, serah terima yang dilakukan secara langsung dan dibolehkan dengan pembayaran (ganti) yang diketahui (Ramadhan 2020, 375). Ijarah dapat dibagi menjadi 2 transaksi menurut objeknya: (a) Ijarah atas manfaat, yaitu pengambilan manfaat dari suatu harta atau benda yang kemudian diganti dengan pembayaran sewa. (b) Ijarah atas pekerjaan atau tenaga, yaitu pengambilan manfaat dari amal, tenaga, atau pekerjaan seseorang yang kemudian diganti dengan pembayaran upah.

\section{Landasan Hukum Ijarah}

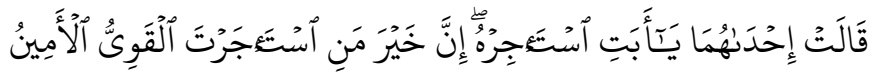

Artinya: "Salah seorang dari kedua wanita itu berkata wahai bapakku ambillah ia sebagai orang yang bekerja dengan kita karena sesungguhnya orang yang paling baik yang kamu ambil untuk bekerja ialah orang yang kuat lagi dapat dipercaya" (QS. Al-Qashas: 26). Maksud dari ayat tersebut menjelaskan bahwa untuk mengambil manfaat dari suatu pekerjaan atau jasa seseorang hendaklah memilih yang kuat dan dapat dipercaya.

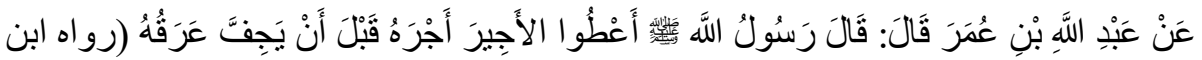

$$
\begin{aligned}
& \text { ماجه) }
\end{aligned}
$$

Artinya: "Dari Abdillah bin Umar ia berkata: Berkata Rasulullah SAW: Berikan upah kepada pekerja sebelum keringatnya kering” (H.R.s Ibnu Majah). Rasulullah SAW. menganjurkan bagi yang menyewa jasa seseorang untuk segera memberikan upahnya sebelum keringatnya kering atau setelah pekerjannya selesai. 
Rukun ijarah ada 4, yaitu: (a) Aqid, terdapat orang yang menyewakan dan orang yang menyewa. (b) Sighat, merupakan ijab dan qabul. (c) Ujrah, yaitu uang sewa atau upah. (d) Manfaat, terdiri dari pengambilan manfaat suatu objek harta atau benda atau pengambilan manfaat dari suatu pekerjaan atau jasa seseorang.

Syarat ijarah ada 4, yaitu: (a) Syarat terjadinya akad, yaitu aqid harus yang berakal dan mumayyiz. (b) Aset harus memberikan manfaat kepada penyewa, karena tanggung jawab pemeliharaan sewa adalah orang yang menyewakan. (c) Jika aset rusak sebelum berakhirnya kontrak, maka akad tersebut tetap berjalan atau masih tetap berlaku. Sedangkan akad ijarah akan berhenti apabila aset tersebut tidak memberikan manfaat kepada penyewa atau. (d) Sebelum akad berakhir, aset tidak boleh dijual kepada penyewa dengan harga yang ditetapkan sebelumnya. Sedangkan apabila akad sudah berkahir, maka aset yang akan dijual boleh ditentukan harganya.

Menurut surat edaran No. 10/14/DPBS yang dikeluarkan bank Indonesia tertanggal 17 Maret 2008, dalam memberikan pembiayaan ijarah BUS atau UUS harus memenuhi langkah berikut ini: (1) Bank bertindak sebagai pemilik dan/atau pihak yang mempunyai hak penguasaan atas objek sewa baik berupa barang atau jasa, yang menyewakan objek sewa dimaksud kepada nasabah sesuai kesepakatan. (2) Barang dalam transaksi ijarah adalah barang bergerak atau tidak bergerak yang dapat diambil manfaat sewanya. (3) Bank wajib menjelaskan kepada nasabah mengenai karakteristik produk pembiayaan atas dasar ijarah, serta hak dan kewajiban nasabah sebagaimana diatur dalam ketentuan bank Indonesia mengenai transparansi informasi produk bank dan penggunaan data pribadi nasabah. (4) Bank wajib melakukan analisis atas rencana pembiayaan atas dasar ijarah kepada nasabah yang antara lain meliputi aspek personal berupa analisa atas karakter dan/atau aspek usaha antara lain meliputi analisa kapasitas usaha, keuangan dan/atau prospek usaha. (5) Objek sewa harus dapat dinilai dan diidentifikasi secara spesifik dan dinyatakan dengan jelas termasuk besarnya nilai sewa dan jangka waktunya. (6) Bank sebagai pihak yang menyediakan objek sewa, wajib menjamin pemenuhan kualitas maupun kuantitas objek sewa serta ketepatan waktu penyediaan objek sewa sesuai kesepakatan. (7) Bank wajib menyediakan dan untuk merealisasikan penyediaan objek sewa yang dipesan nasabah. (8) Bank dan nasabah wajib menuangkan kesepakatan dalam bentuk perjanjian tertulis berupa akad pembiayaan atas dasar ijarah. (9) Pembayaran sewa dapat dilakukan baik dengan angsuran maupun sekaligus. (10) Pembayaran sewa tidak dapat dilakukan dalam bentuk piutang maupun dalam bentuk pembebasan utang. (11) Bank dapat meminta nasabah untuk menjaga keutuhan objek sewa, dan menanggung biaya pemeliharaan objek sewa sesuai dengan kesepakatan dimana uraian pemeliharaan yang bersifat material dan struktural harus dituangkan dalam akad, dan bank tidak dapat meminta nasabah untuk bertanggungjawab atas kerusakan objek sewa yang terjadi bukan karena pelanggaran akad atau kelalaian nasabah.

\section{Non Performing Financing (NPF)}

Pada perbankan syariah, istilah Non Performing Loan (NPL) diganti dengan $N P F$ karena dalam bank syariah menggunakan prinsip pembiayaan berbeda dengan bank konvensional yang menggunakan istilah kredit. Rasio ini digunakan untuk mengukur tingkat permasalahan pembiayaan yang dihadapi oleh 
bank syariah. $N P F$ adalah jumlah pembiayaan yang bermasalah dan kemungkinan tidak dapat di tagih, semakin besar nilai $N P F$ maka akan menjadikan dampak buruk bagi kinerja bank tersebut. Resiko pembiayaan meningkat, margin atau bunga kredit akan meningkat pula. Dalam perbankan Islam tidak mengenal instrumen bunga karena yang digunakan adalah margin atau bagi hasil itu pada keuntungan ataupun pada kerugian sesuai dengan kesepakatan. Resiko yang terjadi dari pembiayaan atau pinjaman adalah peminjaman yang tertunda atau ketidak mampuan peminjam untuk membayar kewajiban yang telah dibebankan. Untuk mengantisipasi hal tersebut maka bank syariah harus mampu menganalisis penyebab permasalahan (Utami and Muslikhati 2019, 38).

Menurut Pernyataan Standar Akuntansi Keuangan (PSAK) No. 31 revisi 2000 paragraf 24, disebutkan bahwa kredit non performing pada umumnya merupakan kredit yang pembayaran angsuran pokok dan/atau bunganya telah lewat sembilan puluh hari atau lebih setelah jatuh tempo, atau kredit yang pembayarannya secara tepat waktu sangat diragukan. Kredit non performing terdiri atas kredit yang digolongkan sebagai kredit kurang lancar, diragukan, dan macet (IAI 2000).

Semakin tinggi $N P F$, maka profitabilitas akan semakin rendah dan sebaliknya, jika NPF semakin rendah, maka profitabilitas akan semakin tinggi. Jika kredit bermasalah sangat besar dan cadangan yang dibentuk juga besar, berakibat modal bank kemungkinan menjadi negatif sehingga laba yang diperoleh menjadi terganggu. Pembiayaan bermasalah dalam jumlah besar akan menurunkan tingkat operasi bank tersebut. Apabila penurunan pembiayaan dan profitabilitas sudah sangat parah sehingga mempengaruhi profitabilitas, likuiditas dan solvabilitas suatu bank, maka kepercayaan para penitip dana terhadap bank akan hilang (Fazriani and Mais 2019). Untuk menghitung rasio NPF, digunakan rumus sebagai berikut:

\section{$N P F=($ Total $N P F /$ Total Pembiayaan $) \times 100 \%$}

\section{Financing to Deposit Ratio (FDR)}

FDR merupakan rasio yang digunakan untuk mengukur likuiditas suatu bank dalam membayar kembali penarikan dana yang dilakukan deposan dengan mengandalkan pembiayaan yang diberikan sebagai sumber likuiditasnya, yaitu dengan cara membagi jumlah pembiayaan yang diberikan oleh bank terhadap dana pihak ketiga (DPK). Semakin tinggi $F D R$, maka semakin tinggi dana yang disalurkan ke DPK. Dengan penyaluran DPK yang besar, maka pendapatan bank $R O A$ akan semakin meningkat, sehingga $F D R$ berpengaruh positif terhadap $R O A$.

Standar yang digunakan bank Indonesia untuk rasio FDR adalah $80 \%$ hingga $110 \%$. Jika angka rasio FDR suatu bank berada pada angka dibawah $80 \%$ (misalkan 60\%), maka dapat disimpulkan bahwa bank tersebut hanya dapat menyalurkan sebesar $60 \%$ dari seluruh dana yang berhasil dihimpun. Karena fungsi utama dari bank adalah sebagai intermediasi (perantara) antara pihak yang kelebihan dana dengan pihak yang kekurangan dana, maka dengan rasio FDR $60 \%$ berarti $40 \%$ dari seluruh dana yang dihimpun tidak tersalurkan kepada pihak yang membutuhkan, sehingga dapat dikatakan bahwa bank tersebut tidak menjalankan fungsinya dengan baik. Kemudian jika rasio FDR bank mencapai lebih dari $110 \%$, berarti total pembiayaan yang diberikan bank tersebut melebihi 
dana yang dihimpun. Oleh karena dana yang dihimpun dari masyarakat sedikit, maka bank dalam hal ini juga dapat dikatakan tidak menjalankan fungsinya sebagai pihak intermediasi (perantara) dengan baik. Semakin tinggi FDR menunjukkan semakin riskan kondisi likuiditas bank, sebaliknya semakin rendah $F D R$ menunjukkan kurangnya efektifitas bank dalam menyalurkan pembiayaan. Jika rasio $F D R$ bank berada pada standar yang ditetapkan oleh bank Indonesia, maka laba yang diperoleh oleh bank tersebut akan meningkat (dengan asumsi bank tersebut mampu menyalurkan pembiayaannya dengan efektif). Rasio ini dirumuskan sebagai berikut (Suryani 2012):

$$
F D R=\begin{array}{l|}
\text { Jumlah Dana Yang Diberikan } \\
\text { Total Dana Pihak Ketiga } \\
\hline
\end{array}
$$

\section{Return on Assets (ROA)}

$R O A$ adalah kemampuan perusahaan dalam memanfaatkan aktivanya untuk memperoleh laba. Rasio ini mengukur tingkat kembalian investasi yang telah dilakukan oleh perusahaan dengan menggunakan seluruh dana (aktiva) yang dimilikinya. Rasio ini dapat diperbandingkan dengan tingkat bunga bank yang berlaku. Untuk menghitung rasio $R O A$ menggunakan rumus sebagai berikut:

$$
R O A=\frac{\text { Laba Bersih }}{\text { Total Aset }} \times 100 \%
$$

Semakin besar $R O A$, berarti semakin besar pula tingkat keuntungan yang dicapai dan semakin baik posisi bank dari segi penggunaan aset. ROA digunakan untuk mengukur profitabilitas bank karena bank ndonesia sebagai pembina dan pengawas perbankan lebih mengutamakan nilai profitabilitas suatu bank yang diukur dengan aset yang dananya sebagian besar dari dana simpanan masyarakat. Semakin besar ROA suatu bank, semakin besar pula tingkat keuntungan yang dicapai bank, dan semakin baik posisi bank tersebut dari segi penggunaan aset.

Salah satu indikator yang digunakan untuk mengukur tingkat profitabilitas adalah ROA. ROA penting bagi bank karena $R O A$ digunakan untuk mengukur efektifitas perusahaan dalam menghasilkan keuntungan dengan mamanfaatkan aktiva yang dimilikinya. ROA merupakan rasio antara laba sesudah pajak terhadap total asset. Semakin besar ROA menunjukkan kinerja perusahaan semakin baik, karena tingkat pengembalian (return) semakin besar.

\section{Unit Usaha Syariah (UUS)}

UUS merupakan unit usaha yang dibentuk oleh bank konvensional, akan tetapi dalam aktivitasnya menjalankan kegiatan perbankan berdasarkan prinsip syariah, serta melaksanakan kegiatan lalu lintas pembayaran. Aktivitas UUS sama dengan aktivitas yang dilakukan oleh BUS, yaitu aktivitas dalam menawarkan produk penghimpunan dana pihak ketiga, penyaluran dana kepada pihak yang membutuhkan, serta memberikan pelayanan jasa perbankan lainnya.

UUS menurut UU No. 21 tahun 2008 (Presiden RI 2008) adalah unit kerja dari kantor pusat BUS yang berfungsi sebagai kantor induk dari kantor atau unit 
yang melaksanakan kegiatan usaha berdasarkan prinsip syariah, atau unit kerja di kantor cabang dari suatu bank yang berkedudukan di luar negeri yang melaksanakan kegiatan usaha secara konvensional yang berfungsi sebagai kantor induk dari kantor cabang pembantu syariah dan/atau unit syariah. Keberadaan bank syariah sebagai bagian dari sistem perbankan nasional diharapkan mendorong perekonomian suatu negara. Tujuan dan fungsi perbankan syariah dalam perekonomian adalah kemakmuran ekonomi yang meluas, tingkat kerja penuh dan tingkat pertumbuhan ekonomi yang optimum, keadilan sosial-ekonomi, dan distribusi pendapatan serta kekayaan yang merata, stabilitas nilai uang, mobilisasi dan investasi tabungan yang menjamin adanya pengembalian yang adil dan pelayanan yang efektif.

Kelembagaan UUS diatur dalam Peraturan Bank Indonesia Nomor 15/14/PBI/2013 tentang Perubahan Atas Peraturan Bank Indonesia Nomor 11/10/PBI/2009 tentang Unit Usaha Syariah (GBI 2013) yang selanjutnya diatur dalam Surat Edaran Bank Indonesia (SEBI) No.15/51/DPbS tertanggal 30 Desember 2013 Perubahan Atas Surat Edaran Bank IndonesiaNomor 11/28/DPbS tanggal 5 Oktober 2009 perihal Unit Usaha Syariah. UUS wajib dibentuk oleh bank yang akan melakukan kegiatan usaha berdasarkan prinsip syariah di kantor pusat bank yang berfungsi sebagai kantor induk dari cabang syariah dan/atau unit syariah. UUS memiliki tugas antara lain: (1) Mengatur dan mengawasi seluruh kegiatan kantor cabang syariahdan/atau unit syariah. (2) Menempatkan dan mengelola dana yangbersumber dari kantor cabang syariah dan/atau unit syariah. (3) Menerima dan menatausahakan laporan keuangan dari kantor cabang syariah dan/atau unit syariah. (4) Melakukan kegiatan lain sebagai kantor induk dari kantor cabang syariah atau unit syariah. Kantor cabang syariah dapat dibuka dengan izin Gubernur bank Indonesia oleh bank yang telah membuka UUS. Pembukaan kantor cabang syariah dapat dilakukan dengan: (a) Membuka kantor cabang syariah yang baru. (b) Mengubah kegiatan usaha kantor cabang yang melakukan kegiatan usaha secara konvensional menjadi kantor cabang syariah. (c) Meningkatkan status kantor di bawah kantor cabang menjadi kantor cabang syariah. Pemberian izin untuk ketiga poin di atas dilakukan dalam dua tahapan, yaitu pertama persetujuan prinsip yang merupakan persetujuan untuk melakukan persiapan pembukaan kantor cabang syariah, dan kedua izin pembukaan kantor cabang syariah. (d) Mengubah kegiatan usaha kantor cabang yang sebelumnya telah membuka unit syariah menjadi kantor cabang syariah. (e) Meningkatkan status kantor cabang pembantu yang sebelumnya telah membuka unit syariah. (f) Membuka kantor cabang syariah baru yang berasal dari unit syariah dari kantor cabang dan/atau kantor cabang pembantu di mana Unit Usaha Syariah sebelumnya berada. Pemberian izin mulai dari poin empat di atas dilakukan secara langsung melalui izin pembukaan kantor cabang syariah. Bank yang memiliki kantor cabang syariah dan unit syariah wajib memiliki pencatatan dan pembukuan tersendiri untuk kegiatan usaha berdasarkan prinsip syariah dan menyusun laporan keuangan kegiatan usaha berdasarkan prinsip syariah (Soemitra 2018, 67-68). 


\section{Gambar 2. Kerangka Pemikiran}

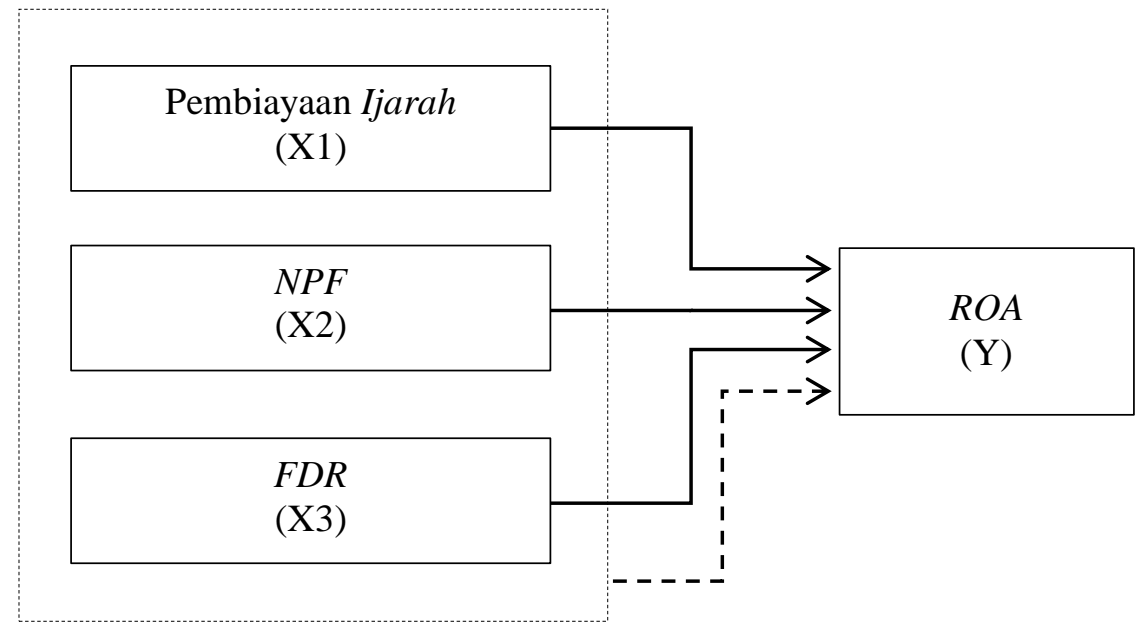

Kerangka pemikiran pada Gambar 2 maksudnya adalah untuk menjelaskan mengenai pengaruh pembiayaan ijarah, NPF dan FDR terhadap ROA pada UUS baik secara parsial maupun simultan. Berdasarkan telaah literatur dan kerangka pemikiran yang telah dijelaskan di atas, maka hipotesis dalam penelitian ini dapat dirumuskan sebagai berikut:

H1 : Pembiyaan ijarah berpengaruh terhadap $R O A$

H2 : $N P F$ berpengaruh terhadap $R O A$

H3 : FDR berpengaruh terhadap $R O A$

H4 : Pembiayaan ijarah, $N P F, F D R$ berpengaruh terhadap $R O A$

\section{METODE PENELITIAN}

Jenis penelitian yang digunakan adalah penelitian asosiatif dengan pendekatan kuantitatif. Variabel yang digunakan adalah variabel bebas (independent) meliputi pembiyaan ijarah, NPF dan FDR serta variabel terikat (dependent) yang meliputi tingkat $R O A$. Sumber data yang digunakan adalah data sekunder yang diperoleh dari website OJK, yaitu https://www.ojk.go.id. Teknik pengambilan sampel menggunakan teknik purposive sampling dengan kriteria sebagai berikut: (a) menerbitkan laporan keuangan triwulan UUS pada tahun 2018-2020, (b) UUS melakukan pembiayaan ijarah selama tahun 2018 sampai 2020, (c) UUS yang pembiayaan ijarahnya tidak bernilai 0 selama periode pengamatan. Berdasarkan kriteria sampel yang ada, dari 23 populasi UUS hanya 5 UUS yang memenuhi kriteria pemilihan sampel sehingga digunakan sebanyak 5 UUS sebagai sampel penelitian dalam 3 tahun periode dengan data triwulan, yaitu bank Danamon Indonesia, bank Permata, bank MayBank Indonesia, bank CIMB Niaga dan bank Sinarmas. Teknik pengumpulan data menggunakan teknik pustaka dan dokumentasi berupa buku, paper jurnal terkait dan laporan keuangan triwulan UUS dari website OJK. Teknik analisa data menggunakan analisis regresi linier berganda dan asumsi klasik dengan menggunakan alat bantu aplikasi SPSS. 


\section{HASIL DAN PEMBAHASAN PENELITIAN}

\section{Uji Normalitas}

Uji Normalitas bertujuan untuk menguji data apakah dalam model regresi variable terikat dan variable bebas keduanya mempunyai distribusi normal atau tidak.

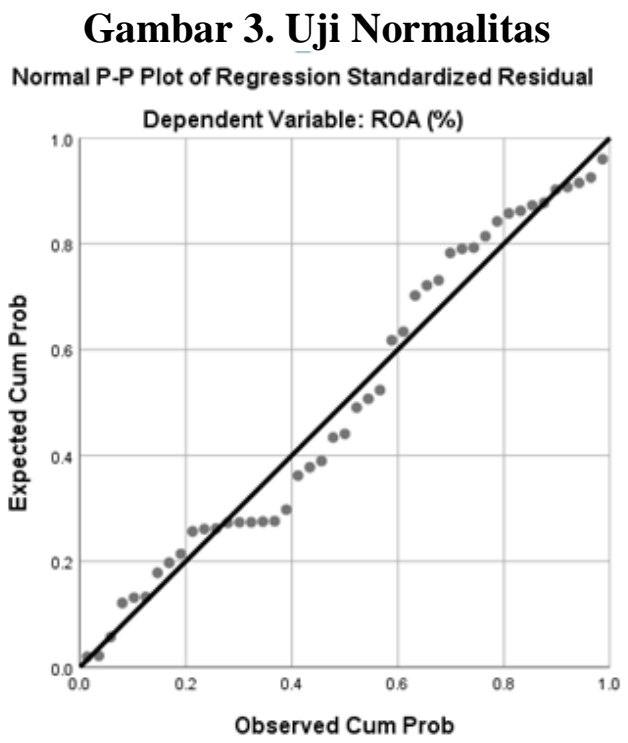

Sumber: Output SPSS

Dari Gambar 3 dapat dilihat bahwa data menyebar disekitar garis diagonal dan mengikuti arah garis diagonal, maka data terdistrubusi dengan normal dan model regresi telah memenuhi asumsi normalitas.

\section{Uji Multikolinieritas}

Uji Multikolinieritas bertujuan untuk menguji apakah dalam suatu model regresi ditemukan adanya korelasi antarindependen atau tidak.

Tabel 2. Uji Multikolinieritas

\begin{tabular}{lcc}
\hline \multirow{2}{*}{ Model } & \multicolumn{2}{c}{ Collinearity Statistics } \\
\cline { 2 - 3 } & Tolerance & VIF \\
\hline Ijarah & 0,916 & 1,092 \\
NPF & 0,708 & 1,413 \\
FDR & 0,764 & 1,308 \\
\hline Sumber: Output SPSS & \multicolumn{2}{c}{}
\end{tabular}

Dari Tabel 2 dapat diketahui bahwa tolerance dari ketiga variabel independent lebih dari 0,1 dan VIF kurang 10, maka dapat dikatakan bahwa dalam model regresi tidak terjadi masalah multikolinieritas.

\section{Uji Heteroskedastisitas}

Menentukan heteroskedastisitas dilakukan dengan menggunakan scatterplot regresi. Gambar 4 merupakan output dari uji heteroskedastisitas dimana diketahui bahwa titik-titik menyebar dengan pola yang tidak jelas diatas 
dan dibawah angka 0 pada sumbu $\mathrm{Y}$, maka data penelitian ini tidak terjadi masalah heteroskedastisitas.

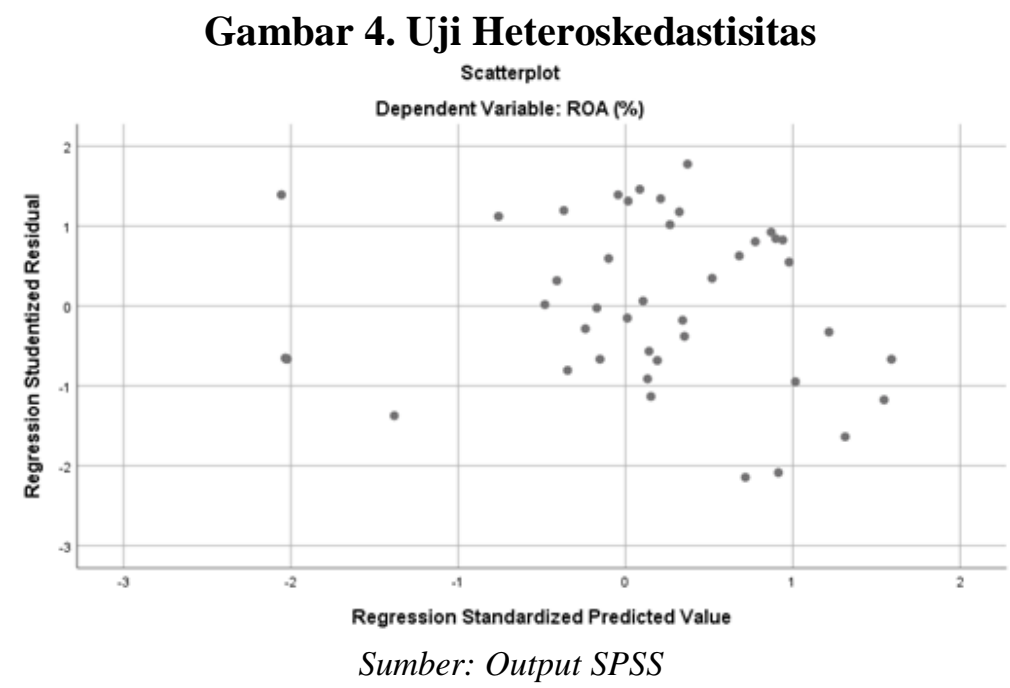

\section{Uji Autokorelasi}

Uji autokorelasi digunakan untuk mengetahui ada tidaknya korelasi serial pada variabel pengganggu. Tidak adanya gejala autokorelasi dapat dibuktikan dengan menggunakan metode Durbin Watson, yaitu jika nilai Durbin Watson terletak antara dU sampai dengan (4-dU).

Tabel 3. Uji Autokorelasi dan Determinasi

\begin{tabular}{lccccc}
\hline Model & $\boldsymbol{R}$ & $\boldsymbol{R}$ Square & $\begin{array}{c}\text { Adjusted } \boldsymbol{R} \\
\text { Square }\end{array}$ & $\begin{array}{c}\text { Std. Error of } \\
\text { the Estimate }\end{array}$ & $\begin{array}{c}\text { Durbin- } \\
\text { Watson }\end{array}$ \\
\hline 1 & $0,680^{a}$ & 0,462 & 0,422 & 0,52574 & 1,797 \\
\hline $\begin{array}{l}\text { a. Predictors: (Constant), Ijarah, FDR, NPF } \\
\text { b. Dependent Variable: } R O A\end{array}$ &
\end{tabular}

Sumber: output spss

Nilai dU dalam penelitian ini diketahui melalui distribusi nilai tabel Durbin Watson berdasarkan k (3) dan N (44) dengan signfikansi 5\% dan pada Tabel 3 nilai Durbin Watson sebesar 1,797, sehingga didapat dU $(1,6647)<$ Durbin Watson $(1,797)<4$-dU $(2,3353)$, maka berdasarkan nilai tersebut maka tidak ada gejala autokorelasi.

\section{Regresi Linier Berganda}

Analisis regresi linier berganda dapat menghitung atau memprediksi besarnya pengaruh dua atau lebih variabel independent terhadap variabel dependent. Berdasarkan Tabel 4 dapat diperoleh persamaan regresi $\mathrm{Y}=-0,015+$ $0,000000118 X_{1}-0,168 X_{2}+0,019 X_{3}=-0,1639$. Nilai konstanta dalam regresi kali ini yaitu $-0,1639$ artinya bahwa $R O A$ akan mengalami penurunan sebesar $-0,1639$ apabila variabel bebas diasumsikan tetap.

Nilai koefisiensi ijarah 0,000000118 menunjukan bahwa jika ijarah naik satu satuan atau 1\%, maka ROA akan naik sebesar 0,000000118 dengan asumsi variabel bebas yang lain tetap. Nilai koefisiensi $N P F-0,168$ menunjukan bahwa 
jika $N P F$ naik satu satuan atau $1 \%$, maka $R O A$ akan turun sebesar $-0,168$ dengan asumsi variabel bebas yang lain tetap. Nilai koefisiensi $F D R$ 0,019 menunjukan bahwa jika $F D R$ naik satu satuan atau 1\%, maka ROA akan naik sebesar 0,019 dengan asumsi variabel bebas yang lain tetap.

Tabel 4. Coefficients ${ }^{a}$

\begin{tabular}{lccccc}
\hline \multirow{2}{*}{ Model } & \multicolumn{2}{c}{$\begin{array}{c}\text { Unstandardized } \\
\text { Coefficients }\end{array}$} & $\begin{array}{c}\text { Standardized } \\
\text { Coefficients }\end{array}$ & \multirow{2}{*}{$\boldsymbol{t}$} & Sig. \\
\cline { 2 - 5 } & $\boldsymbol{B}$ & $\begin{array}{c}\text { Std. } \\
\text { Error }\end{array}$ & Beta & & \\
\hline (Constant) & $-0,015$ & 0,158 & & $-0,097$ & 0,923 \\
\hline Ijarah & $1,180 \mathrm{E}-7$ & 0,000 & 0,120 & 0,995 & 0,326 \\
\hline$N P F$ & $-0,168$ & 0,054 & $-0,385$ & $-3,079$ & 0,004 \\
\hline FDR & 0,019 & 0,003 & 0,733 & 5,741 & 0,000 \\
\hline $\begin{array}{l}\text { a. Dependent Variable: } \text { ROA } \\
\text { Sumber: Output SPSS }\end{array}$ & & & & \\
\end{tabular}

\section{Uji Hipotesis}

Uji $\mathrm{t}$ atau uji parsial bertujuan untuk mengetahui apakah variabel independent (pembiayaan ijarah, NPF dan FDR) secara individu berpengaruh terhadap variabel dependent ROA. Kriteria pengambilan keputusan uji t, yaitu jika nilai signifikan $<0,05$ atau $5 \%$ maka hipotesis diterima, artinya variabel independent mempunyai pengaruh terhadap variabel dependent.

Pada Tabel 4, didapat bahwa nilai signifikan ijarah $(0,326)>0,05$, artinya H1 ditolak atau dengan kata lain pembiayaan ijarah tidak berpengaruh terhadap $R O A$. Nilai signifikan $N P F(0,004)<0,05$, artinya $\mathbf{H 2}$ diterima atau $N P F$ berpengaruh terhadap $R O A$. Sedangkan nilai $F D R(0,000)<0,05$, artinya $\mathbf{H 3}$ diterima atau $F D R$ berpengaruh terhadap ROA. Kemudian pada Tabel 4 dapat dilihat bahwa nilai beta tertinggi yaitu $F D R$ sebesar 0,733 dibandingkan variabel independent lainnya, yaitu pembiayaan ijarah dan $N P F$. Hal ini menunjukkan bahwa $F D R$ merupakan variabel independent yang paling dominan mempengaruhi $R O A$ di UUS. Artinya, semakin baik FDR maka semakin baik pula ROA di UUS begitu pula sebaliknya.

Tabel 5. Anova

\begin{tabular}{lccccc}
\hline \multicolumn{1}{c}{ Model } & $\begin{array}{c}\text { Sum of } \\
\text { Squares }\end{array}$ & $\boldsymbol{d f}$ & $\begin{array}{c}\text { Mean } \\
\text { Square }\end{array}$ & $\boldsymbol{F}$ & \multirow{2}{*}{ Sig. } \\
\hline Regression & 9,512 & 3 & 3,171 & 11,471 & $0,000^{\mathrm{b}}$ \\
Residual & 11,056 & 40 & 0,276 & & \\
Total & 20,568 & 43 & & & \\
\hline
\end{tabular}

a. Dependent Variable: ROA

b. Predictors: (Constant), Ijarah, NPF, FDR

Sumber: Output SPSS

Uji $\mathrm{F}$ atau uji koefisien regresi secara simultan, yaitu untuk mengatahui pengaruh variabel independent secara simultan terhadap variabel dependent, apakah berpengaruh atau tidak. Dari hasil Tabel 5 dapat diketahui bahwa nilai signifikansinya adalah 0,000 dibawah 0,05 atau 5\% menunjukkan bahwa variabel independent secara simultan yang diwakili oleh pembiayaan ijarah, NPF dan 
$F D R$ berpengaruh signifikan terhadap variabel dependent $R O A$, sehingga dapat dikatakan bahwa $\mathbf{H 4}$ diterima.

\section{Koefisien Determinasi}

Pada Tabel 3 nilai koefisien determinasi atau $R$ Square sebesar 0,462 atau $46,2 \%$. Hal ini menunjukkan bahwa variabel independent pembiayaan ijarah, $N P F$ dan FDR berpengaruh terhadap naik turunnya variabel dependent ROA sebesar 46,2 \% dan sisanya $53.8 \%$ merupakan dari variabel lain yang tidak dimasukkan dalam model regresi. Sedangkan korelasi (R) nilainya 0,680 berarti hubungan antara variabel dependent dengan variabel independent dapat dikatakan hubungan yang kuat dan erat karena nilainya mendekati 1 .

\section{Pengaruh Pembiyaan Ijarah Terhadap ROA}

Berdasarkan hasil penelitian, pembiayaan ijarah tidak mempunyai pengaruh signifikan positif terhadap ROA pada Unit Usaha Syariah. Ditunjukkan dengan tingkat signifikansi di atas 0,05 yaitu sebesar 0,326 yang berarti hipotesis yang menyatakan pembiayaan ijarah berpengaruh signifikan positif terhadap $R O A$ pada UUS ditolak.

Hasil penelitian ini sesuai dengan penelitian yang dilakukan oleh (Rizqi et al. 2017) yang menemukan bahwa ijarah tidak berpengaruh signifikan terhadap profitabilitas. Namun disisi lain, hasil penelitian ini tidak sinkron dengan teori yang digunakan dalam penelitian ini, yaitu ijarah memiliki manfaat dan tujuan yang jelas, serah terima yang dilakukan secara langsung dan dibolehkan dengan pembayaran (ganti) yang diketahui. Dalam teori ini juga dijelaskan surat edaran No. 10/14/DPBS yang dikeluarkan bank Indonesia tertanggal 17 Maret 2008, dalam memberikan pembiayaan ijarah BUS atau UUS harus memenuhi langkahlangkah yang dapat menguntungkan terhadap perbankan maupun nasabah. Jadi dengan adanya pembiayaan ijarah akan berpengaruh positif terhadap ROA perusahaan. Karena semakin besar ROA menunjukkan kinerja perusahaan semakin baik, kerena tingkat pengembalian (return) semakin besar.

\section{Pengaruh NPF Terhadap ROA}

Berdasarkan hasil penelitian, NPF mempunyai pengaruh signifikan positif terhadap ROA pada UUS. Ditunjukkan dengan tingkat signifikansi di bawah 0,05 yaitu sebesar 0,004 yang berarti hipotesis yang menyatakan NPF berpengaruh signifikan positif terhadap ROA pada UUS diterima.

Secara teori hasil penelitian ini sesuai dengan teori yang digunakan penelitian ini yang menyatakan bahwa $N P F$ merupakan jumlah pembiayaan yang bermasalah dan kemungkinan tidak dapat di tagih. Semakin besar nilai $N P F$ maka akan menjadikan dampak buruk bagi kinerja bank tersebut. Peningkatan jumlah $N P F$ akan meningkatkan jumlah penyisihan penghapusan aktiva produktif (PPAP) yang perlu dibentuk oleh pihak bank. Jika hal ini terjadi terus menerus maka perusahaan tidak mengalami keuntungan bahkan akan mengurangi modal bank. Resiko pembiayaan meningkat, margin atau bunga kredit akan meningkat pula. Peningkatan NPF tersebut secara logika akan mengurangi terhadap ROA perusahaan dalam hal ini adalah UUS.

Hasil penelitian ini tidak konsisten dengan penelitian yang dilakukan oleh (Roy 2018) yang menunjukkan bahwa NPF tidak memiliki pengaruh yang 
signifikan terhadap ROA UUS di Indonesia. Apabila terjadi peningkatan jumlah pembiayaan bermasalah $N P F$ pada suatu bank, maka tidak akan menurunkan jumlah $R O A$ pada bank tersebut.

\section{Pengaruh FDR terhadap ROA}

Berdasarkan hasil penelitian, $F D R$ mempunyai pengaruh signifikan positif terhadap $R O A$ pada UUS. Ditunjukkan dengan tingkat signifikansi di bawah 0,05 yaitu sebesar 0,000 yang berarti hipotesis yang menyatakan $F D R$ berpengaruh signifikan positif terhadap ROA pada UUS diterima.

Hasil penelitian ini sesuai dengan penelitian yang dilakukan oleh (Yusuf 2017) yang menunjukkan hasil bahwa $F D R$ memiliki pengaruh terhadap $R O A$ BUS. Disamping itu hasil ini juga sesuai dengan teori dimana FDR merupakan rasio yang digunakan untuk mengukur likuiditas suatu bank dalam membayar kembali penarikan dana yang dilakukan deposan dengan mengandalkan pembiayaan yang diberikan sebagai sumber likuiditasnya, yaitu dengan cara membagi jumlah pembiayaan yang diberikan oleh bank terhadap dana pihak ketiga (DPK). Semakin tinggi $F D R$, maka semakin tinggi dana yang disalurkan ke DPK. Dengan penyaluran DPK yang besar, maka pendapatan bank $R O A$ akan semakin meningkat, sehingga FDR berpengaruh positif terhadap $R O A$.

Rasio keuangan bisa bermanfaat karena digunakan dalam membantu untuk pengambilan keputusan. Manfaat tersebut digunakan dalam memprediksi perubahan laba, yaitu diukur dengan signifikan atau tidaknya hubungan antara rasio keuangan dengan perubahan laba. Apabila hubungan antara rasio keuangan dan perubahan laba mengalami signifikan, berarti rasio keuangan tersebut bermanfaat dalam memprediksi perubahan laba. Sebaliknya, apabila hubungan antara rasio keuangan dan perubahan laba tidak signifikan, berarti rasio keuangan tersebut tidak dapat digunakan dalam memprediksi perubahan laba.

\section{Pengaruh Pembiayaan Ijarah, NPF, FDR Terhadap ROA}

Berdasarakan hasil penelitian, pembiayaan ijarah, NPF, dan FDR berpengaruh secara simultan terhadap $R O A$. Hal tersebut dapat dilihat dari tingkat signifikansi sebesar 0,000 dibawah 0,05 atau 5\% menunjukkan bahwa hipotesis yang menyatakan variabel independent secara simultan yang diwakili oleh pembiayaan ijarah, NPF dan FDR berpengaruh signifikan terhadap variabel dependent ROA pada UUS diterima. Pengaruh tersebut tergolong tinggi karena semua variabel independent mampu melakukan sebesar 0,462 atau 46,2\%. Hal ini menunjukkan bahwa variabel independent (pembiayaan ijarah, NPF dan FDR) terhadap naik turunnya variabel dependent ROA adalah sebesar 46,2 \% dan sisanya 53,8 \% merupakan dari variabel lain yang tidak dimasukkan dalam model regresi.

\section{KESIMPULAN}

Setelah dilakukan penelitian, ternyata pembiayaan ijarah secara parsial tidak berpengaruh terhadap $R O A$. Sedangkan variabel $N P F$ dan FDR secara parsial berpengaruh terhadap ROA UUS. FDR menjadi variabel independent yang paling dominan diantara $N P F$ dan pembiayaan ijarah. Secara parsial dari ketiga variabel independent tersebut, para stakeholder dapat menggunakan variabel FDR 
dalam memprediksi $R O A$. Kemudian secara simultan pembiayaan ijarah, NPF dan $F D R$ berpengaruh terhadap ROA pada UUS dengan besar pengaruh $46.2 \%$, yang artinya pembiayaan ijarah, NPF dan $F D R$ berpengaruh terhadap naik turunnya $R O A$ sebesar $46.2 \%$ dan sisanya $53.8 \%$ dipengaruhi oleh faktor lain. Untuk menjelaskan faktor-faktor lain yang berpengaruh terhadap ROA UUS diperlukan penelitian lebih lanjut. Diharapkan bagi peneliti selanjutnya untuk memperpanjang masa penelitian dan menggunakan variabel lain dalam menentukan ROA bagi UUS karena masih ada ruang penelitian sebesar 53,8\%.

\section{DAFTAR PUSTAKA}

Ascarya, Ascarya. 2006. "Comparing Islamic Banking Development in Malaysia and Indonesia: Lessons for Instruments Development". Paper Presented on Periodic Discussion Directorate of Monetary Management Bank Indonesia, 1-61.

Fazriani, Anisya Dwi and Rimi Gusliana Mais. 2019. "Pengaruh Pembiayaan Mudharabah, Musyarakah, Dan Murabahah Terhadap Return On Asset Melalui Non Performing Financing Sebagai Variabel Intervening (Pada Bank Umum Syariah Yang Terdaftar Diotoritas Jasa Keuangan)”. (JAM) Jurnal Akuntansi Dan Manajemen, 16 (1): 1-34. https://doi.org/10.36406/jam.v16i01.265.

Ghozali, Mohammad, Muhammad Ulul Azmi, and Wahyu Nugroho. 2019. "Perkembangan Bank Syariah Di Asia Tenggara: Sebuah Kajian Historis". Falah: Jurnal Ekonomi Syariah, 4 (1): 44-55. https://doi.org/10.22219/jes.v4i1.8700.

Gubernur Bank Indonesia. 2013. Peraturan Bank Indonesia Nomor 15/14/PBI/2013 tentang Perubahan atas Peraturan Bank Indonesia Nomor 11/10/PBI/2009 tentang Unit Usaha Syariah. https://www.bi.go.id/id/archive/arsipperaturan/Documents/pbi_151413.pdf.

Ikatan Akuntansi Indonesia. 2000. Pernyataan Standar Akuntansi Keuangan (PSAK) No. 31 (Revisi 2000) tentang Akuntansi Perbankan Syariah. https://alengwee.files.wordpress.com/2011/10/psak-31-akuntansiperbankan.pdf

Imam, Imam. (2021). Ijarah adalah Hukum Sewa Properti Islami. rumah123.com. Retrieved December 3, 2021, from https://www.rumah123.com/panduanproperti/menyewakan-properti-66952-ijarah-adalah-hukum-sewa-propertiislami-

id.html\#: :text=Ijarah\%20thumma\%20al\%20bai',barang\%20itu\%20menja di\%20hak\%20milik

Mas'adi, Ghufron A. 2002. Fikih Muamalah Kontekstual. Jakarta: Raja Grafindo Persada.

Marimin, Agus, Abdul Haris Romadhoni, and Tiara Nur Fitria. 2015. "Perkembangan Bank Syariah di Indonesia". Jurnal Ilmiah Ekonomi Islam (JIEI), 1 (2): 75-87. http://dx.doi.org/10.29040/jiei.v1i02.30.

Permata, Russely Inti Dwi, Fransisca Yaningwati, and Zahroh Z. A. 2014. "Analisis Pengaruh Pembiayaan Mudharabah dan Musyarakah terhadap 
Tingkat Profitabilitas (Return On Equity) (Studi pada Bank Umum Syariah yang terdaftar di Bank Indonesia Periode 2009-2012)". Jurnal

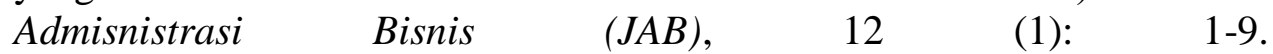
http://administrasibisnis.studentjournal.ub.ac.id/index.php/jab/article/view/ 486.

Presiden Republik Indonesia. 2008. Undang-Undang Republik Indonesia Nomor 21 Tahun 2008 tentang Perbankan Syariah. Otoritas Jasa Keuangan. https://www.ojk.go.id/waspadainvestasi/id/regulasi/Documents/UU_No_21_Tahun_2008_Perbankan_Sya riah.pdf

Ramadhan, Abu HF. 2020. Terjemah Fathul Qarib. Surabaya: Mutiara Ilmu.

Rizqi, Nuril Wahidah, Noor Shodiq Askandar, and Afifudin Afifudin. 2017. "Analisis Pengaruh Pembiayaan Mudharabah, Musyarakah, dan Ijarah terhadap Profitabilitas Bank Syariah di Indonesia (Studi Empiris Pada Bank Umum Syariah yang Listing di Otoritas Jasa Keuangan Periode 2010-2016). Jurnal Ilmiah Riset Akuntansi, 6 (5): 91-104. http://www.riset.unisma.ac.id/index.php/jra/article/view/301.

Roy, Mochamad Indrajit. 2018. "Pengaruh Rasio Keuangan terhadap Rasio Profitabilitas Unit Usaha Syariah di Indonesia". Jurnal Banque Syar'i: Jurnal Ilmiah Perbankan Syariah, 4 (2): 113-122. http://dx.doi.org/10.32678/bs.v4i2.1128.

Santoso, Harun, and Anik Anik. 2015. "Analisis Pembiayaan Ijarah pada Perbankan Syariah". Jurnal Ilmiah Ekonomi Islam (JIEI), 1 (2): 106-116. http://dx.doi.org/10.29040/jiei.v1i02.33.

Soemitra, Andri. 2018. Bank dan Lembaga Keuangan Syariah. Jakarta: Kencana. Suryani, Suryani. 2012. "Analisis Pengaruh Financing To Deposit Ratio (FDR) Terhadap Profitabilitas Perbankan Syariah Di Indonesia (Rasio Keuangan Pada Bus Dan Uus Periode 2008-2010)". Economica: Jurnal Ekonomi Islam, 2 (2): 153-174. https://doi.org/10.21580/economica.2012.2.2.854.

Utami, Mayvina Surya Mahardhika and Muslikhati Muslikhati. 2019. "Pengaruh Dana Pihak Keiga (DPK), Capital Adequacy Ratio (CAR), Non Performing Financing (NPF) terhadap Likuiditas Bank Umum Syariah (BUS) Periode 2015-2017'. Falah: Jurnal Ekonomi Syariah, 4 (1): 33-43. https://doi.org/10.22219/jes.v4i1.8495.

Yusuf, Muhammad. 2017. "Dampak Indikator Rasio Keuangan terhadap Profitabilitas Bank Umum Syariah di Indonesia". Jurnal Keuangan Dan Perbankan, 13 (2): 141-151. http://journal.ibs.ac.id/index.php/jkp/article/view/53. 